\title{
ANOTHER CORINTHIAN ERASTUS INSCRIPTION ${ }^{1}$
}

\author{
Andrew D. Clarke
}

Ever since the Corinthian discovery in 1929 of a mid-first century $A D$ pavement dedicated by a Roman official named Erastus there has been much speculative discussion as to the likelihood of there being a common identity between the Erasti mentioned in the New Testament and the Erastus of the Corinthian pavement. ${ }^{2}$ Since the archaeological discovery of the Erastus pavement, it has been agreed amongst those who discuss the problem in relation to the epigraphic evidence that there is just the one inscription, the pavement, and the New Testament evidence which draw attention to an Erastus in Corinth. ${ }^{3}$

\section{Erastus Vitellius}

In addition to the famous pavement, however, a further Corinthian inscription mentioning an Erastus was found in 1960 which has not as yet been brought into discussion of the biblical Erastus. The inscription was originally discovered not far from the northern cemetery of Corinth, in a region locally known as Skoutéla - immediately north of the centre of Corinth and half-way between the plateau and the site of the ancient city itself. This was published at a later date by D.I. Pallas and

\footnotetext{
${ }^{1}$ References throughout giving only author will be to the person's commentary on Romans. For a more detailed discussion of the New Testament and archaeological evidence regarding the question of identity between the Corinthian Erasti see the author's forthcoming Cambridge University PhD thesis discussing secular and Christian leadership in 1 Corinthians 1-6. I am grateful to Drs. D.W.J. Gill, B.W. Winter and Miss J. Reynolds for most helpful discussion on the whole Erastus question.

${ }^{2}$ For an extensive bibliography and the most recent discussion of the problems related to a connection between the Erastus of the pavement and that of Romans 16:23, see David W.J. Gill, 'Erastus the Aedile', TynB 40 (1989) 293-301.

${ }^{3}$ Cf. J.H. Kent, The Inscriptions 1926-1950 (Corinth viii, 3, Princeton, 1966) 99;

V.P. Furnish, 'Corinth in Paul's time. What can Archaeology tell us?', Biblical Archaeology Review 15 (1988) 20;
} 
S.P. Dantes. ${ }^{4}$ Their partial restoration of the text of the inscription reads: 5

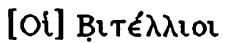

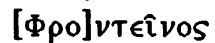

[Kà E] paotos

$[\tau \hat{\omega}]-\gamma \in \dot{v} \in \mathbf{l}$

$[---]$

This translates as:

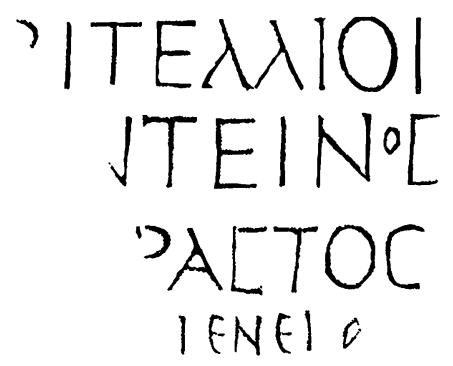

[The] Vitellii,

[Fro]ntinus

[and E]rastus

(dedicate this ) [to] -

$[--\cdot]$

The plaque is made of white marble with existing dimensions 0.275 (width) $\times 0.28$ (height) $\times 0.027$ meters (thickness). The height of the lettering is $0.040-0.045$ meters, with width of 0.025 meters. The style of the lettering has suggested a second century AD dating. ${ }^{6}$

The slab is complete on its right side, but the whole of the left side is missing which poses some problems for reconstruction. ${ }^{7}$ The of from the first line is questionable, and

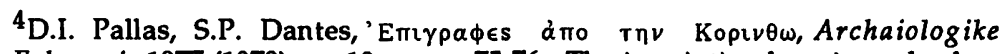
Ephemeris 1977 (1979) no. 19, pages 75-76. The inscription has since also been published in SEG 29 (1979) no. 301, but only with a brief commentary. The important find was not included by J.H. Kent, The Inscriptions 1926-1950 (Corinth viii, 3, Princeton, 1966 )

${ }^{5}[]$ indicate lost text. $O$ indicate an expansion of the Greek text. The inscription is reproduced with the kind permission of the American School of Classical Studies, Corinth Excavations.

${ }^{6}$ The varying style of the epsilon and sigma in the inscription, (sometimes angular, and sometimes lunate); also the lambda with its protruding right stem, $\lambda$, as opposed to the more usual $\Lambda$; and the final omicron of Frontinus being of a smaller size than the other letters, have all suggested to Dantes and Pallas a second century dating. The editors have drawn parallels in lettering style with two other Corinthian inscriptions, (Corinth viii, 1, 103 and Corinth viii, 3, 201, both dated from the second century).

7J. Reynolds has been particularly helpful in her comments regarding possible reconstructions of the text and dating of the lettering. 
may as easily have been the initials $\Lambda \Lambda$, for the praenomina of

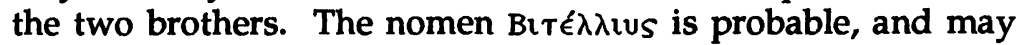
then be linked with the relatively common name Vitellius. The family name would appear to have been local, and not notably prominent. It may have been the case that the family at some point achieved citizenship through the patronage of a member from the Vitellius family, and that Erastus and Frontinus may have been descendants of freed slaves. The name Erastus is also probable, given that it is syntactically likely that the two cognomina are joined by a kat in some form. ${ }^{8}$

Pallas and Dantes in their commentary on the inscription suggest that the dedication plaque may originally have formed part of a sun-dial. 9 It projected from the base of a statue or altar which the two Vitellii dedicated, for the sake of the family, to the divinity whose name may well have been inscribed in line 5 . It is by no means clear, however, that there was a fifth line to the dedication. Instead, it may have been the case that the name of the divinity appears only on the

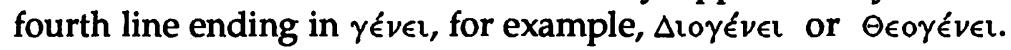

It would also appear probable that the two Vitellii, Frontinus and Erastus, who dedicated the plaque were brothers. At present there is no other reference to the Vitellius family in Corinth. ${ }^{10}$ A Frontina is mentioned, however, in a Corinthian inscription dating from the time of Hadrian; ${ }^{11}$ and there is, of course, the first century pavement laid by Erastus.

\section{'Erastus' in Literary and Non-Literary Sources}

The coming to light of this further inscription to a Corinthian Erastus brings into focus once again the significance of how

\footnotetext{
${ }^{8}$ The possibility remains that instead of $k a$ ì there may have been a $\kappa \epsilon$, or even a ligatured $\kappa \epsilon$, both of which would occupy less space and allow for a longer cognomen than Erastus.

${ }^{9}$ This is not included amongst the three sun-dials from Corinth which have been catalogued in Sharon L. Gibbs, Greek and Roman Sundials (New Haven and London, 1976) 3016G, 3017G, 3018G, 5004G.

${ }^{10}$ This use of the plural is not paralleled elsewhere in the Corinthian epigraphic corpus; Pallas and Dantes, however, offer the similar occurrence

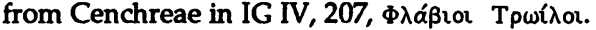

${ }^{11}$ Cf. B.D. Meritt, The Greek Inscriptions 1896-1927 (Corinth viii, 3, Cambridge, Massachusetts, 1931) 80, Ka that the name Frontinus is more commonly found in inscriptions from Asia Minor.
} 
infrequently the cognomen Erastus is found in Hellenistic Greek. It will be helpful to consider some of the occurrences of the name, looking first at the literary sources, and secondly at the non-literary sources.

The name is mentioned three times in the New Testament. ${ }^{12}$ In each case Erastus is found to be an acquaintance of Paul. It has also been possible to see a connection with both Corinth and Ephesus in each of these references, as Cadbury has pointed out. ${ }^{13}$ New Testament commentators, however, are generally doubtful as to the possibility of one and the same man being referred to in each of these New Testament references. ${ }^{14}$ Outside the New Testament, this Erastus is referred to in the works of Basil, Epiphanius and John Chrysostom. ${ }^{15}$

The one other Erastus who is mentioned more than once in Greek literary sources is a Socratic philosopher. Originating from Scepsis, he is frequently referred to in conjunction with Coriscus. This Erastus is mentioned in Plato's thirteenth letter, and is the addressee of his sixth letter. ${ }^{16}$

Turning to the non-literary sources, Hemer, in his substantial work on the historicity of Acts, has pointed out that outside the New Testament material the name Erastus, is perhaps less common than often appreciated. 17 Noting, however, that Paul sends Erastus to Ephesus (Acts 19:22),

${ }^{12}$ Acts 19:22; Romans 16:23; 2 Timothy 4:20.

${ }^{13}$ H.J. Cadbury, 'Erastus of Corinth', JBL 50 (1931) 45.

${ }^{14}$ Those commentators on Romans against the identification include, Dunn, Cranfield, Michel, Murray, Leenhardt, Meyer, Philippi and Wilckens. E.B. Redlich, S. Paul and his Companions, (London, 1913) 231-2, amongst others, argues in favour of a connection.

15 Basil, Constitutiones asceticae 31.1324; Epiphanius, Index discipulorum 123; John Chrysostom, In acta apostolorum 60.295.

${ }^{16}$ See G.R. Morrow, Plato's Epistles: A Translation, with Critical Essays and Notes, (Indianopolis, 1962) $212 \mathrm{n}$. 3. He is also mentioned by name in Clement of Alexandria, Stromata 5.14.102; Diogenes Laertius, Lives 3.46, 61; Eusebius, Praeparatio Evangelica 11.16.1, 13.13.27; Olympiodorus, In Platonis Alcibiadem commentarii 6.12; Origen, Contra Celsum 6.12, Commentarii in evangelium Joannis 20.43.406; Strabo, Geography 13.1.54.

${ }^{17}$ C.J. Hemer, The Book of Acts in the Setting of Hellenistic History, (Tübingen, 1989) 235. Cranfield and H.A.W. Meyer suggest the name was common. 
Hemer does indicate epigraphic instances of Erasti from that city. ${ }^{18}$

Closer to Corinth, an Erastus who was furthermore an archon at Athens in $163 / 2 \mathrm{BC}$, is also known. A marble stele was found in the Athenian Agora inscribed with two decrees which were passed during the archonship of Erastus. ${ }^{19}$ Another inscription from Athens, dated to $164 / 3$ BC, names an Epartos

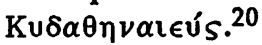

A number of other instances of Erasti have been found covering a broad geographical area and time period. ${ }^{21}$ It remains the case, however, that the name Erastus is relatively uncommon in the either the literary or non-literary Greek sources, although little can be argued from this statistic. ${ }^{22}$

\section{Conclusion}

Although this second inscription offers no direct help to the problem of affirming the probability of an identification between the first century Erasti of Corinth, the occurrence of this second inscription does, however, raise once again the whole problem of making an identification between people who are mentioned in both literary and epigraphic sources. Hemer argues that this problem will generally be present in such instances of identification, except in the case of significant people known to secular history. ${ }^{23}$

\footnotetext{
${ }^{18} \mathrm{C}$.J. Hemer, The Book of Acts, 235., The best example is the Ti. Claudius Erastus from a Curetes list dated to AD 54-59, referring to the son of the prytanis named at the head of the list, (I. Eph. 1008.8). The example in MM $\left(S I G^{3} 838=S I G^{2} 388\right)$ is also a leading Ephesian, but is later (= I. Eph. 1487, Ephesus, AD 128-29).'

${ }^{19}$ Cf. Hesperia III (1934) no. 20, 11. 2, 33, (cf. also Hesperia XIII, p 266 (20).

${ }^{20}$ Hesperia XXXVI (1967) pp. 89, no. 19, 122.

${ }^{21}$ SEG 11, 622 (Laconia, Hadrian's reign), and 994 (Messenia, second or first century B.C.); SEG 25, 194 (Attica, third or second century B.C.); SEG 28, 1010 (Erastus of Memmius, Bithynia, second or third century A.D.); CIG 269; 1241 (Sparta); 1249 (Sparta); 6378. These cover the broad span from the third century BC to the third century AD. I am grateful to D.W.J. Gill for drawing my attention to some of these instances.

${ }^{22}$ It should be noted also that in the Latin inscriptions of CIL a number of references are found to Erasti. Van de Weerd in 'Een nieuw opschrift van Korinthe', Revue Belge de Philologie et d'Histoire 10 (1931) 41, finds some 40 instances, 38 of which he places in Italy, including 18 from Rome.

${ }^{23}$ See Hemer, The Book of Acts, 235 n.40, and 224 n. 13.
} 
The question is raised, however, as to what might constitute significant evidence. Turning to Hemer again, he allows that cumulative local evidence may well change the significance of apparently circumstantial material; he notes, "The accumulation of insignificant parallels may point beyond the intrinsic evidential value of the individual items."24

An identification between Erastus Vitellius and Erastus, companion of Paul, can confidently be rejected on two grounds: firstly, the date of the inscription is second century, and secondly, it appears that the inscription is a pagan dedication.

In the case of the earlier inscription, that of Erastus the aedile, however, a rejection of identification cannot be as confidently maintained. On the contrary, there are two significant pieces of information in the inscription which might well favour identification. The pavement is dated to the midfirst century; and there is evidence to support that the post of aedile, inscribed on the pavement, and that of oikovónos $\tau \hat{\eta} s$ $\pi \delta ́ \lambda \in \omega s$ from Romans 16:23, may have been identical. ${ }^{25}$

There are significant grounds for exclusion in the case of the later inscription. With regard to the first century Corinthian aedile, however, the grounds for exclusion are not certain, and identification should remain therefore a significant possibility. It may indeed be the case that in the Corinthian Pauline community there was a prominent civic leader and wealthy benefactor.

${ }^{24}$ Hemer, The Book of Acts, 221.

${ }^{25}$ Theissen, The Social Setting of Pauline Christianity (Edinburgh, 1982) 81, concedes that this remains a possibility although he is generally not convinced. He does not refer, however, to the evidence of H.J. Mason, Greek Terms for Roman Institiutions - A Lexicon and Analysis, American Studies in Papyrology XIII, (Hakkert, Toronto 1974) 71, $175 \mathrm{f}$. where epigraphic evidence that àyopavópos and oikovónos are equivalent expressions in a Roman municipium or colony. 